\title{
COMMENTARY
}

\section{Human fetal pancreatic islet-like structures as source material to treat type 1 diabetes}

\author{
Yasuhiro Ikeda ${ }^{1}$ and Yogish C Kudva ${ }^{2^{*}}$ \\ See related research by Zhang et al., http://stemcellres.com/content/4/6/141
}

\begin{abstract}
The incidence of type 1 diabetes is increasing worldwide. Current therapy continues to be suboptimal. An exciting therapeutic advance in the short term is closed loop technology development and application. However, cell and tissue therapy continues to be an unmet need for the disorder. Human islets isolated from deceased donors will be clinically available to treat type 1 diabetes within the next 1 to 2 years. Other approaches such as xenotransplantation and islet products derived from human embryonic stem cells and induced pluripotent stem cells are currently being pursued. The current commentary provides context and discusses future endeavors for transplantation of islet-like structures derived from fetal pancreas.
\end{abstract}

\section{Introduction}

In this issue of Stem Cell Research and Therapy, Zhang and colleagues report results of their attempts to isolate, culture and transplant islet-like structures from human fetal pancreatic progenitor cells seeking to develop such therapy for type 1 diabetes (T1D) [1]. T1D is characterized by severe insulin deficiency [2] - although its most common and dramatic manifestation is in childhood, it can occur at any age. Currently, the disorder is treated with insulin replacement using multiple daily insulin injections, an insulin pump or an insulin pump with continuous glucose sensor augmentation. The recent approval of the first closed loop therapy for the disorder in the US by the Food and Drug Administration, following the publication of its efficacy, represents a major step forward in treatment of the disorder [3]. However, further improvements in closed loop therapy and additional

\footnotetext{
* Correspondence: Kudva.yogish@mayo.edu

2Endocrinology, Mayo Clinic College of Medicine, Rochester, MN 55905, USA Full list of author information is available at the end of the article
}

options continue to be required for adequate treatment of the disorder. Such options include glucose responsive cell or tissue therapy. Currently, whole organ pancreas transplantation is available and islet product from deceased donor pancreata will likely be approved within the next 1 to 2 years as clinical therapy for T1D associated with frequent, severe hypoglycemia. Both therapies are associated with the need for chronic immunosuppression and shortage of donor organs.

With consent from research subjects and approval of the local Ethics committee, Zhang and colleagues obtained pancreata from several fetuses at 10 to 12 weeks gestational age [1]. They isolated islet-like structures using standard collagenase-based separation techniques from these pancreata and subsequently expanded and differentiated them in vitro. Various appropriate markers were evaluated in vitro after differentiation. The islet like structures reversed hyperglycemia when transplanted under the renal capsule of nude mice rendered chemically diabetic. Nephrectomy of the kidney bearing the islet-like structure transplants restored hyperglycemia, providing proof for function of the transplanted islet-like structures.

Research with human fetal tissues needs to be conducted with appropriate checks and balances. The current work was done working within such regulations. These checks and balances, as well as ethical concerns, may make research involving human fetal tissues very difficult and this is a likely explanation for the lack of or limited number of studies starting with such source material to date. Fetal tissue was clinically used for patients with Parkinson's disease about 20 years ago by three independent research groups [4-6]. An Editorial in the same issue comprehensively addressed ethical, societal and political issues associated with such work [7]. To date, work using such tissue continues to be limited in extent. Recently, human fetal pancreatic bud-derived cells from 7- to 11-week-old fetuses were used to establish a genetically engineered human pancreatic beta cell 
line, which reversed chemically induced diabetes in mice [8]. The current study represents the first of its kind attempting work with fetal islet-like structures as source material to generate transplantable material without transformation of the tissue. Many centers have, over the past 15 years, worked with alternative source material, such as human embryonic stem cells (ESCs) or, more recently, induced pluripotent stem cells (iPSCs) [9], with the latter offering the great advantage of being autologous. Each of these exciting areas of research needs to be pursued further to make more treatment choices available for patients with diseases such as T1D.

As such exciting work continues, laboratory and experimental challenges lie ahead. The current manuscript, being the first of its kind, used techniques based on experimental protocols from ESC and iPSC culture. Important areas for future research involving fetal pancreas tissue as source material include: (i) definition of source material, including minimum characteristics, such as proportion of cells that are CD133-positive (used by Zhang and colleagues); (ii) culture media and growth factors required for expanding islet-like structures; (iii) molecular/staining criteria to identify islet-like structures suitable for starting differentiation protocols; and (iv) culture media, stages and duration of each stage to induce differentiation. It is also important to monitor the glucose-responsiveness of the fetal tissue-derived islets, as neonatal beta cells generally show immature beta cell phenotypes with limited glucose-responsiveness [10-14]. Future clinical applications also require (i) release criteria for the islet product, (ii) appropriate animal models to evaluate the efficacy of the islet product, (iii) efficacy and safety data from animal experiments, and (iv) identification of appropriate human subjects for phase 1 and 2 studies. We realize that several of these challenges also apply to ESC and iPSC studies. Expansion of work in each of these fields offers great opportunity for crossfertilization and acceleration of therapy development.

\section{Conclusion}

It is concerning that the incidence of T1D is increasing globally even as we approach 100 years since the discovery and subsequent therapeutic use of insulin to treat the disorder [15]. As we approach the centennial landmark, the progress in 'closed loop' therapy development is heartening. Efficient testing of alternative therapies, such as transplantation of various cell products from allo and auto sources, will require team efforts across disciplines and clinical centers on the one hand and patients and families on the other. The study reported by Zhang and colleagues expands the source material available to develop new therapies. Advancing this work will require scientific and clinical teams to innovate while conforming to appropriate regulatory boundaries.

\section{Abbreviations}

ESC: Embryonic stem cell; iPSC: induced pluripotent stem cell; T1D: Type 1 diabetes.

\section{Competing interests}

The authors declare that they have no competing interests.

\section{Author details}

'Molecular Medicine Program, Mayo Clinic College of Medicine, Rochester, MN 55905, USA. 'Endocrinology, Mayo Clinic College of Medicine, Rochester, MN 55905, USA.

Published: 30 Dec 2013

\section{References}

1. Zhang WJ, Xu SQ, Cai HQ, Men XL, Wang Z, Lin H, Chen L, Jiang YW, Liu HL, $\mathrm{Li} C \mathrm{CH}$, Deng HK, Lou JN: Evaluation of islets derived from human fetal pancreatic progenitor cells in diabetes treatment. Stem Cell Res Ther 2013, 4:141.

2. Bluestone JA, Herold K, Eisenbarth G: Genetics, pathogenesis and clinical interventions in type 1 diabetes. Nature 2010, 464:1293-1300.

3. Bergenstal RM, Klonoff DC, Garg SK, Bode BW, Meredith M, Slover RH, Ahmann AJ, Welsh JB, Lee SW, Kaufman FR: Threshold-based insulin-pump interruption for reduction of hypoglycemia. N Engl J Med 2013, 369:224-232.

4. Freed CR, Breeze RE, Rosenberg NL, Schneck SA, Kriek E, Qi JX, Lone T, Zhang YB, Snyder JA, Wells TH: Survival of implanted fetal dopamine cells and neurologic improvement 12 to 46 months after transplantation for Parkinson's disease. N Engl J Med 1992, 327:1549-1555.

5. Spencer DD, Robbins RJ, Naftolin F, Marek KL, Vollmer T, Leranth C, Roth RH, Price LH, Gjedde A, Bunney BS, Sass KJ, Elsworth JD, Kier EL, Makuch R, Hoffer PB, Redmond DJ Jr: Unilateral transplantation of human fetal mesencephalic tissue into the caudate nucleus of patients with Parkinson's disease. N Engl J Med 1992, 327:1541-1548.

6. Widner H, Tetrud J, Rehncrona S, Snow B, Brundin P, Gustavii B, Bjorklund A, Lindvall O, Langston JW: Bilateral fetal mesencephalic grafting in two patients with parkinsonism induced by 1-methyl-4-phenyl-1,2,3,6-tetrahydropyridine (MPTP). N Engl J Med 1992, 327:1556-1563.

7. Kassirer JP, Angell M: The use of fetal tissue in research on Parkinson's disease. N Engl J Med 1992, 327:1591-1592.

8. Ravassard P, Hazhouz Y, Pechberty S, Bricout-Neveu E, Armanet M, Czernichow $P$, Scharfmann R: A genetically engineered human pancreatic beta cell line exhibiting glucose-inducible insulin secretion. J Clin Invest 2011, 121:3589-3597.

9. Rezania A, Bruin JE, Riedel MJ, Mojibian M, Asadi A, Xu J, Gauvin R, Narayan K, Karanu F, O'Neil JJ, Ao Z, Warnock GL, Kieffer TJ: Maturation of human embryonic stem cell-derived pancreatic progenitors into functional islets capable of treating pre-existing diabetes in mice. Diabetes 2012, 61:2016-2029.

10. Bliss $C R$, Sharp GW: Glucose-induced insulin release in islets of young rats: time-dependent potentiation and effects of 2-bromostearate. Am J Physiol 1992, 263:E890-E896.

11. Aguayo-Mazzucato C, Zavacki AM, Marinelarena A, Hollister-Lock J, El Khattabi I, Marsili A, Weir GC, Sharma A, Larsen PR, Bonner-Weir S: Thyroid hormone promotes postnatal rat pancreatic beta-cell development and glucose-responsive insulin secretion through MAFA. Diabetes 2013, 62:1569-1580.

12. Espinosa-de-los M, Driscoll SG, Steinke J: Insulin release from isolated human fetal pancreatic islets. Science 1970, 168:1111-1112.

13. Tuch BE, Jones A, Turtle JR: Maturation of the response of human fetal pancreatic explants to glucose. Diabetologia 1985, 28:28-31.

14. Hawdon JM, Aynsley-Green A, Alberti KG, Ward Platt MP: The role of pancreatic insulin secretion in neonatal glucoregulation. I. Healthy term and preterm infants. Arch Dis Child 1993, 68:274-279.

15. Knip M: Descriptive epidemiology of type 1 diabetes - is it still in? Diabetologia 2012, 55:1227-1230.

\section{$10.1186 /$ scrt389}

Cite this article as: Ikeda and Kudva: Human fetal pancreatic islet-like structures as source material to treat type 1 diabetes. Stem Cell Research \& Therapy 2013, 4:159 